\title{
Managerial Competency of Principal
}

\author{
Syarifah Munawarah* \\ Master of Education Administration Student \\ Syiah Kuala University \\ Banda Aceh, Indonesia \\ *syarifahmunawarah@gmail.com
}

\author{
Murniati A.R., Niswanto \\ Master Study Program of Educational Administration \\ Syiah Kuala University \\ Banda Aceh, Indonesia \\ murisna60@ymail.com.niswanto@unsyiah.ac.id.
}

\begin{abstract}
Managerial competence is a skill that includes planning, implementing, organizing and monitoring. The purpose of this study was to determine how the principal managerial, including: Program planning; program implementation; supervision; and supporting factors that support the smooth running of school programs. Through a qualitative approach with descriptive methods, data collection techniques are carried out through interviews, observation, and documentation study. The research subjects were the principal, deputy head of curriculum, teachers and school committees at MI Bait Qurany Saleh Rahmany Banda Aceh. The results found: program planning is well prepared and efficient referring to the curriculum established by the Ministry of Religion with superior school programs including the tahfidz class program, calligraphy extracurricular activities, speech, Arabic, archery and teacher quality improvement programs; Teachers, school staff and parents responded very well to the program implementation; Supervision is carried out through the principal directly in the field and a monitoring team that coordinates with the principal through the WA group; Supporting factors for the running of school programs, namely the existence of complete and adequate facilities in schools, qualified human resources such as classroom teachers, tahfidz teachers and qualified staff as well as good support from the government and foundations for school programs.
\end{abstract}

Keywords—managerial competence, principal

\section{INTRODUCTION}

Education is a human effort to develop human abilities and potentials so that humans can live properly, both individually and as members of society. Education is a sector that largely determines the quality of a nation.

Education is an important factor that can change the nation's generation to be more advanced in thinking, acting and being able to change their character and character so that they become human beings who have noble character and are useful for the country and the nation. Efforts to realize a good quality education must consider various aspects related to education so that not only the quality but the quality of student learning achievement increases both academically and in everyday life. In the structure of the school's organizational program the principal is the main person responsible for improving the quality of the school, so a school principal must have competencies, one of which is managerial competence.

Principal managerial relationship and teacher achievement motivation with teacher teaching effectiveness is very strong [1]. With the existence of a professional school principal, the policy issued will encourage teachers to be more enthusiastic in teaching. Managerial competence of a head is needed to achieve quality, relevant, effective and efficient goals. If what you want to achieve or improve is the quality of learning, the head must carry out his managerial functions properly and effectively. All of them really require competence and professionalism to enable the creation of dynamic quality interactions. From this explanation, MI Bait Qurany Saleh Rahmany Banda Aceh, which is led by the principal, must be able to empower educators and education personnel as well as all complete school facilities to be able to realize a quality, smooth and productive learning process. These requirements are part of the principal managerial implementation.

Apart from school principals, staff and teachers are also very important in determining the success of improving the quality of education that is oriented towards classroom learning. In particular, teachers must also be professional by mastering their field of study and being able to prepare learning tools before entering class. Learning management planning is carried out by teachers by preparing a number of the needs of students by paying attention to the development of science, technology, and art as a whole and continuously [2]. A teacher must be able to prepare learning tools before starting the learning class not only at MI Bait Qurany in other schools as well. Learning planning implemented by Islamic Education teachers is prepared in accordance with the syllabus development guidelines by referring to $\mathrm{SK}$ and $\mathrm{KD}$ as well as formulating indicators, compiling lesson plans and making scenarios prepared in accordance with the provisions of learning activities [3]. So learning planning must be in accordance with the syllabus and the provisions of learning activities and a knowledge teacher must be in accordance with the times. The difference is that in MI Bait Qurany the preparation of learning devices refers to the curriculum provided by the Ministry of Religion (KEMENAG).

From some of the quotes above, we can see that there are several problems that occur at school if a principal does not have good managerial competence because the principal is the 
manager in the school so that all stake holders can run well according to their goals. Good managerial skills will be able to compile programs, run programs, and also carry out evaluations properly so that they can improve if there are problems and future problems. The purpose of this study was to determine how the principal managerial includes: Program planning, program implementation, supervision and supporting factors that support the smooth running of school programs.

\section{RESEARCH METHODS}

The research approach used in this research is a qualitative approach using descriptive methods., namely research methods that describe the conditions of the research subject at the time the research was carried out by observation, interviews and documentation. Qualitative research is a process of exploring and understanding the meaning of individual and group behavior, describing social or humanitarian problems [4]. The focus of the study in this study is how the principal managerial competence of MI Bait Qurany Saleh Rahmany Banda Aceh. Sources of data in this study were school principals, Waka Curriculum, Committees and Teachers at MI Bait Qurany Saleh Rahmany Banda Aceh. The data collected is processed using qualitative data analysis methods which include the stages, namely: reducing data, presenting data, drawing conclusions, and verifying data.

\section{RESULTS AND DISCUSSION}

\section{A. Program Planning}

Results showed that the school principal's program at MI Bait Qurany Saleh Rahmany Banda Aceh was well-structured and efficient, both for the programs for students, teachers, and employees in the Bait Qurany Saleh Rahmany school environment in Banda Aceh. in the curriculum that has been established by the Ministry of Religion (KEMENAG) and foundations and prepared at the beginning of the new school year by involving teachers and staff in schools. The implementation is good enough. The planned program is to improve the capacity / quality of human resources, especially teachers with a certain schedule on Saturdays, and the principal approaches the teacher before entering class for teaching preparation, provides guidance and training in curriculum preparation, lesson plans and so on and holds meetings with all parties through class discussion program that can accommodate all problems that occur in the field, and hold a consultation program with educational consultants/education experts in improving the quality of schools. The program for students provides comfortable facilities, complete educational facilities and the Takfiz Qur'an class program, Arabic language training, and extracurricular activities including learning calligraphy, speech, archery and foreign languages English and Arabic.

From the results above, the principal tries to organize a program properly by involving all stakeholders in the school so that the goals of the school's vision and mission are achieved starting with compiling a program plan from the school principal. Determining a series of actions to achieve a desired result and planning is the determination of the objectives, procedures, budget and programs of an organization [5]. The principal must be able to carry out the planning process, both short term planning, medium term planning, and long-term planning. From this expert opinion, the principal has prepared a good plan and is in accordance with the applicable procedures in the school by taking several approaches, one of which is a familial or collective approach with a system of meetings and deliberations in the preparation of school programs.

\section{B. Program Implementation Strategy}

Based on the results of the study, it can be concluded that the implementation of the principal's program has been responded very well by teachers and school staff as well as parents of students, all programs run smoothly as expected even though there are only obstacles to individual students because the child development process is different- different as well as the characters. However, all stake holders try hard to handle it, especially teachers by optimizing individual approaches outside of lessons such as communicating to parents about their child's development. In carrying out school program activities, the school takes a kinship approach both to teachers, staff and students here the principal acts as a parent to teachers and staff and the teacher acts as a parent to students so that school programs run smoothly.

In addition to the cooperation of principals, teachers, staff and parents, complete facilities and infrastructure are also needed for the smooth learning process so that teachers can be more confident in teaching. Learning facilities and infrastructure are important factors that affect learning outcomes, regular school buildings, the availability of class and laboratory facilities, the availability of textbooks, media/learning aids are important components that can support the realization of student learning activities [6]. With adequate facilities and infrastructure, it will facilitate all learning activities effectively and efficiently. Especially in the learning of cultural arts which basically requires supporting tools/demonstrations in practical material so that the learning process runs well.

\section{Supervision}

Based on the results of the research, the supervision carried out in addition to involving the monitoring team, the principal also directly supervised in the field every day by way of every morning before entering class the principal had a discussion with the teacher about teaching preparation and if any obstacles and complaints were found, he would immediately evaluate it in the afternoon so that the problem is quickly resolved. Likewise, regarding the problem of teacher and staff attendance. In addition to direct information on the ground, they will also be updated through the WA group. Likewise, if there are problems with students, the school will guide the students in the school, if they cannot, the school will call the parents to the school. Likewise, with the teacher performance improvement program which is held every Saturday at 7: 3012-00 noon. In addition, we can assess the quality of learning 
from outside parties such as from the national accreditation body team and from the public's interest in schools.

The supervision carried out by the principal is quite good, Supervision activities by the principal will have a psychological effect on teacher performance [7]. Teachers who are satisfied with the supervision by the principal will work voluntarily which in turn can increase teacher work productivity. But if the teacher is not satisfied with the implementation of supervision by the principal, the teacher is less enthusiastic at work, this results in decreased teacher productivity. Here we clearly see that supervision from the principal is very important so that subordinates can work optimally.

\section{Supporting Factors}

The supporting factor for the smooth implementation of the first school program is the support factor from the government in this case the Ministry of Religion and support from the foundation itself, school facilities and infrastructure have been provided by the foundation and are complete and the media already exist and the school uses educational consultants/ education experts. to improve teacher competence and abilities. Human resources are already very good, like teachers and other education personnel, just need to upgrade the program according to the times. Other supporters such as the very large amount of support from the parents for school programs so that the school program can run as expected in the school's vision and mission.

Supporting factors are very important for the smooth implementation of existing programs in schools. From the results of the research, it is clear that all parties are very supportive of the school program both from the government, the principal, teachers, staff and parents of students in the school environment. Thus, all programs implemented can run well according to the desired goals.

\section{CONCLUSION}

- Program planning is well-organized and efficient, both programs for teachers, school staff and students refer to the curriculum set by the ministry.

- In the implementation of the program, the teacher, school staff and parents responded very well, there were almost no obstacles even though there were obstacles from individual learners who were difficult to develop but could be overcome.

- In addition to the monitoring team, supervision is carried out by the principal who directly supervises in the field every day by way of every morning before entering the class the principal discusses with the teacher about teaching preparation and if there are obstacles and complaints that are found will be immediately evaluated in the afternoon so that the problem quickly resolved.

- Supporting factors include complete facilities, adequate supporting infrastructure and qualified human resources of teachers who are constantly improving their abilities. Besides, the foundation and the government support them well.

- The principal is an important school factor that determines the direction of the policy for school progress according to the school's vision and mission. Therefore, a qualified and professional principal is needed.

- Managerial competence of a school principal is a very important aspect and must also be accompanied by professional teacher resources in their fields and school facilities that support so that what is desired from educational goals can be achieved in accordance with the school program.

\section{ACKNOWLEDGMENTS}

Thank you to the head of MI Bait Qurany Saleh Rahmany Banda Aceh and also related parties both within the Bait Qurany Saleh Rahmany school in Banda Aceh and outside the school who have helped to make this research smooth.

\section{REFERENCES}

[1] S. Susanti, "Pengaruh Manajerial Kepala Sekolah Dan Motivasi Berprestasi Guru Terhadap Efektifitas Mengajar Guru," Jurnal Administrasi Pendidikan, vol. 12, pp. 72-81, 2010.

[2] C. Mutia, C.Z. Harun, and N. Usman, "Manajemen pembelajaran melalui pendekatan kurikulum tingkat satuan pendidikan dalam meningkatkan prestasi belajar siswa di SMA Negeri 1 Mesjid Raya Aceh Besar," Jurnal Administrasi Pendidikan: Program Pascasarjana Unsyiah, vol. 4, pp. 23-31, 2016.

[3] A. Huseyinli and N. Usman, "Manajemen Guru dalam Meningkatkan Mutu Pembelajaran Pendidikan Agama Islam di SMA Fatih Bilingual School Lamlagang Banda Aceh," Jurnal Administrasi Pendidikan: Program Pascasarjana Unsyiah, vol. 2, pp. 109-119, 2014.

[4] S. Sugiyono, Educational Research Methods with Quantitative Approaches, Qualitative, and R \& D. Bandung: Alfabeta, 2015.

[5] M. Mustari, Manajemen Pendidikan. Jakarta: PT Raja Grafindo Persada, 2015.

[6] D. Aunurrahman, Belajar dan pembelajaran. Bandung: Alfabeta, 2009.

[7] S. Satriadi, "Pengaruh Pengawasan Kepala Sekolah terhadap Kinerja Guru pada SD Negeri Binaan Tanjung Pinang," Journal of Economic and Economic Education, vol. 4, pp. 288-295, 2016. 